\title{
Aleš Nagode \\ Cecilijanizem na Slovenskem kot glasbeno, kulturno in družbeno vprašanje
}

Disertacija $\mathrm{v}$ uvodu sintetično predstavlja organski razvoj programa cecilijanskega gibanja, ki se je razmahnilo v sedemdesetih letih 19. stoletja, sprva v nemških, potem pa po skoraj vseh deželah katoliške Evrope ter celo med izseljenci v ZDA. Njegov izvor išče $\mathrm{v}$ stoletnih prizadevanjih katoliške cerkve, da bi našla srednjo pot med izkoriščanjem močnega psihološkega učinka, ki ga ima glasba na poslušalca in strahom pred vdiranjem čutnega in posvetnega $v$ liturgijo. Tako se dotakne številnih dokumentov, od spisov cerkvenih očetov do papeških listin in koncilskih odlokov. Posebno pozornost namenja neposrednemu oblikovanju cecilijanskega programa, ki ga lahko zasledujemo skozi celo 19. stoletje, od prvih reformnih poskusov v Franciji in Italiji, do temeljnih spisov romantične glasbene estetike, del E. T. A. Hoffmanna, L. Tiecka in Wackenroderja. Slednji so na prepričanju, da je glasba izraz časa $\mathrm{v}$ katerem nastaja, postulatu umetniške avtonomije navkljub utemeljili načelo, da ustvarjanje nove cerkvene glasbe $v$ razkristjanjenemu stoletju, kakršno je devetnajsto sploh ni mogoče, ter da tako ostaja le historistično obnavljanje starega repertoarja (koral, vokalna polifonija 16. st.) in epigonsko posnemanje le-tega.

$\mathrm{Z}$ ustanovitvijo Cecilijinega društva za ljubljansko škofijo leta 1877 je cecilijanstvo seglo tudi na Slovensko. Disertacija poskuša $z$ vrsto spisov in pregledom dejavnosti številnih pomembnih osebnosti (Rihar, Slomšek, K. Mašek, Nedved, Anton Foerster) iz časa med letom 1840 in formalno ustanovitvijo Cecilijinega društva pokazati, da cecilijanska reforma ni bila le prenos programa nemškega cecilijanstva na Slovensko, temveč, da je bila zavest o nujnosti reforme cerkvene glasbe, pa tudi pot zanjo znana že prej. Disertacija poskuša na podlagi spisov slovenskih cecilijancev podrobno definirati izhodišča njihovega delovanja, ter stališča do 
posameznih vprašanj, kot so raba slovenskega jezika v liturgiji, glasbeno-estetska izhodišča, stilna podoba primerne cerkvene glasbe, odnos do starejše slovenske cerkveno-glasbene literature, pogledi na vlogo koralnega petja, sodelovanje ljudstva pri izvajanju cerkvene glasbe, ipd. Cecilijanski program se pri tem opazovanju izkaže kot logično izpeljan sistem nazorov o cerkveni glasbe, utemeljen na brezpogojnem spoštovanju cerkvenih predpisov glede glasbe v liturgiji, ki terjajo univerzalnost in objektivnost cerkvene glasbe. Njegovo temeljno izhodišče, tako za produkcijo kot reprodukcijo, je izključevanje vsakršne subjektivnosti (izraza osebe) in nacionalnosti (izraza nacije), ter popolna podreditev glasbe liturgični funkciji in s tem besedilu.

Avtor poskuša prikazati tudi odmeve in rezultate uresničevanja cecilijanskega programa $v$ slovenski glasbi, kulturi in politiki. Ob tem opozarja na dejstvo, da je nastop cecilijanskega gibanja sovpadel $\mathrm{z}$ izjemnim razmahom narodne prebuje $\mathrm{v}$ osemdesetih letih prejšnjega stoletja, ter hkratno politično polarizacijo, katere nosilec je bilo vedno številčnejše slovensko meščanstvo. Iz predstavljenega gradiva lahko razberemo, da je reforma cerkvene glasbe naletela na odpor obeh političnih taborov. Liberalni je $s$ svojo težnjo po čim močnejšem prežemanju družbenega življenja z nacionalno idejo nasprotoval zlasti doslednemu vztrajanju cecilijancev pri cerkvenih predpisih o liturgičnem jeziku in univerzalnem značaju cerkvene glasbe. Konservativni tabor, zlasti duhovščina, pa se je bala zlasti pastoralne neučinkovitosti cecilijanske zasnove cerkvene glasbe, ter ljudskih odporov pri uvajanju novotarij.

Avtor v zaključku poskuša strniti izsledke v enotno oceno, ter ugotavlja, da slovensko cecilijansko gibanje ni bilo ovira za razmah glasbenega romantizma in nacionalne glasbe na Slovenskem, temveč prej pomemben del uveljavljanja romantične glasbene estetike na Slovenskem. Ob tem je močno spodbudilo razvoj glasbene publicistike in založništva (prva slovenska glasbena revija Cerkveni glasbenik, zalaganje skladb in učbenikov) in dvig izvajalske ravni širom po Sloveniji (orglarska šola, tečaji, ustanavljanje zborov, pevske šole, itd.). Njegovi voditelji pa so pri prenašanju njegovih univerzalnih idej spregledali specifičen položaj slovenske cerkvene glasbe, ter njene vpetosti v porajajočo se nacionalno kulturo. Čas za dokončno ločitev posvetnega in cerkvenega v slovenski glasbi je napočil šele nekaj desetletij kasneje.

Obranjeno 20. novembra 1997 na Filozofski fakulteti v Ljubljani. 


\section{Cecilianism in Slovenia as a Musical, Cultural, and Social Issue}

In the introduction the dissertation synthetically presents the organic development of the programme of Cecilian movement which spread itself in the 1870s at first in the German and then in nearly all countries of the Catholic Europe and even among the emigrants in the United States. It seeks its source in the centuries-long endeavours of the Catbolic church to find a middle course between utilizing the strong psychological effect which music exerts on listeners and the fear of the irruption of sensual and secular elements into liturgy. It thus touches on numerous documents, from writings by church fathers to papal documents and council decrees. Special attention is paid to the direct formation of the Cecilian programme, which can be traced throughout the 19th century, from the first reform attempts in France and in Italy to the basic texts of the romantic musical aesthetics, to the works of E.T.A. Hoffmann, L. Tieck and Wackenroder. In their belief that music is an expression of time in which it is created these authors, disregarding the principle of autonomy in art, substantiated the principle that the creation of new church music is in a de-Christianized century like the 19th not possible at all and that accordingly one is left with merely restoring the old repertoire (choral, vocal polyphony of the 16th century) and epigonic imitation thereof.

With the founding of the Cecilian Society for the Ljubljana diocese in 1877 Cecilianism reached also Slovenia. Through a number of their writings and a survey of the activities of the key figures (Rihar, Slomšek, Kamilo Mašek, Anton Nedvĕd, Anton Foerster) from the time between the year 1840 and the formal founding of the Cecilian Society the dissertation seeks to demonstrate that the Cecilian reform was not only a transfer of the programme of the German Cecilianism to Slovenia but the awareness of how necessary it was to reform church music and also the way to achieve this were known already at an earlier stage. On the basis of writings by Slovene Cecilians the dissertation attempts to define in possible detail the starting points for their activity and the attitudes to particular topics, like the use of the Slovene language in liturgy, musical and aestbetic starting points, stylistic picture of appropriate church music, the attitude toward older Slovene church music literature, views on the role of choral singing, folk singing in performing church music, etc. In an examination of these issues the Cecilian programme proves to be a logically coberent system of views on church music, grounded on unconditional respect of church rules as regards universalism and objectivity in church music. Its basic point of departure, both for production and reproduction, is the exclusion of any subjectivity (expression of person) or nationality (expression of nation) and the complete subordination of music to the liturgic function and in this way to the text. 
The author tries to present also the responses and results of pursuing the Cecilian programme in Slovene music, culture, and politics. In this connection attention is called to the fact that the appearance of the Cecilian movement coincided with the exceptional growth of national awakening in the eighties of the previous century and a simultaneous political polarization the exponent of which was the steadily increasing Slovene middle classes. From the material put forward it is possible to see that the reform of church music met with resistance on the part of both political camps. The liberal camp, in its desire for ever stronger permeating of social life with the national idea, opposed particularly the consistent insistence of Cecilians on church rules concerning the liturgic language and the universal character of church music. The conservative camp, in particular clergy, feared especially pastoral inefficiency resulting from the Cecilian design of church music and people's disinclination as regards the introduction of novelties.

In the conclusion the author seeks to sum up bis findings into a unified appraisal; be finds that the Slovene Cecilian movement was not an impediment to the rise of musical romanticism and of national music in Slovenia but sooner a significant part od affirmation of romantic musical aesthetics in Slovenia. It gave a strong impetus to the development of musical publicizing and publishing (the first Slovene musical review, Church Musician; publishing of compositions and textbooks) as well as to the rise of the reproduction level throughout Slovenia (organ school, musical courses, founding of choirs, schools for singing, etc.). But its leaders - in transmitting its universal ideas - failed to see the specific position of the Slovene church music and its incorporation within the emerging national culture. The time for a definitive dissociation of secular and clerical elements in Slovene church music was to arrive only a few decades later.

Defended on November 11, 1997, Pbilosopbical Faculty, Ljubljana. 